\title{
Gastrointestinal and ectoparasites of plumbeous rail, Pardirallus sanguinolentus (Aves: Rallidae) in Central Chile
}

\author{
Gastrointestinais e ectoparasitas do saracura-do-banhado, Pardirallus sanguinolentus \\ (Aves: Rallidae) do Chile central \\ José Osvaldo Valdebenito ${ }^{1}$; Lucila Moreno²; Carlos Barrientos ${ }^{3}$; Sergey Mironov ${ }^{4}$; John Mike Kinsella ${ }^{5}$; \\ Armando Cicchino ${ }^{6}$; Mabel Mena ${ }^{7}$; Alexandra Grandón-Ojeda ${ }^{7}$; Daniel González-Acuña ${ }^{7 *}$

\begin{abstract}
${ }^{1}$ Biodiversity Laboratory, Department of Biology and Biochemistry, University of Bath, Bath, United Kingdom
${ }^{2}$ Departamento de Zoología, Facultad de Ciencias Naturales y Oceanográficas, Universidad de Concepción, Concepción, Chile

${ }^{3}$ Escuela de Medicina Veterinaria, Universidad Santo Tomás, Concepción, Chile

${ }^{4}$ Zoological Institute, Russian Academy of Sciences, Universitetskaya Embankment 1, Saint Petersburg, Russia

${ }^{5}$ Helm West Lab, Missoula, MT, United States of America

${ }^{6}$ Universidad Nacional de Mar del Plata, Mar del Plata, Argentina

${ }^{7}$ Laboratorio de Parasitología y Enfermedades de Fauna Silvestre, Departamento de Ciencia Animal, Facultad de Ciencias Veterinarias, Universidad de Concepción, Chillán, Chile
\end{abstract}

Received February 22, 2018

Accepted May 3, 2018

\begin{abstract}
With the aim to identify the parasite fauna of plumbeous rail, Pardirallus sanguinolentus (Aves: Rallidae) in Chile, 26 carcasses were parasitologically necropsied. The present study revealed the presence of 14 species of parasites (inverse Simpson index $=4.64$; evenness $=0.332$ ), including ectoparasites: feather mites: Analloptes megnini, Grallobia sp., Grallolichus sp., Megniniella sp., and Metanalges sp.; the feather lice Pseudomenopon meinertzhageni, Rallicola andinus, and Fulicoffula sp.; and six species of gastrointestinal helminths: Heterakis psophiae, Porrocaecum ardeae, Tetrameres sp., Capillaria sp., Diorchis sp., and Plagiorhynchus sp. The relatively high parasite richness that was found could be attributed to the highly favorable conditions of wetlands for parasite development. All parasites found, except feather lice, are new records for plumbeous rail. A checklist of parasites for plumbeous rail is presented.
\end{abstract}

Keywords: Parasites, helminths, diversity, wetlands, rallids.

\section{Resumo}

Com o objetivo de identificar a fauna parasitária do saracura-do-banhado, Pardirallus sanguinolentus (Aves: Rallidae) no Chile, 26 carcaças foram necropsiadas. O presente estudo revelou a presença de 14 espécies de parasitos (índice Simpson inverso = 4,64; equitatividade = 0,332), incluindo os ácaros de penas: Analloptes megnini, Grallobia sp., Grallolichus sp., Megniniella sp. e Metanalges sp.; os piolhos de penas Pseudomenopon meinertzhageni, Rallicola andinus e Fulicoffula sp.; e seis espécies de helmintos gastrointestinais: Heterakis psophiae, Porrocaecum ardeae, Tetrameres sp., Capillaria sp., Diorchis sp. e Plagiorhynchus sp. A riqueza parasitária relativa encontrada pode ser devido às condiçôes altamente favoráveis das zonas úmidas para o desenvolvimento do parasita. Todos os parasitos encontrados, com exceção dos piolhos de pena, são novos registros para o saracura-do-banhado. Um checklist dos parasitos do saracura-do-banhado é apresentado.

Palavras-chave: Parasitos, helmintos, diversidade, zona úmida, ralídeos.

\section{Introduction}

Parasite-host associations reveal valuable information about the host that should always be considered for studies of biodiversity and conservation (PÉREZ-PONCE DE LEÓN \& GARCÍA-PRIETO,

*Corresponding author: Daniel González-Acuña. Laboratorio de Parasitología y Enfermedades de Fauna Silvestre, Facultad de Ciencias Veterinarias, Universidad de Concepción, Casilla 537, Chillán, Chile. e-mail: danigonz@udec.cl.
2001), particularly since parasites have been linked to important variations in biodiversity, population declines, and even species extinction (e.g., JOHNSON et al., 1999; CUNNINGHAM \& DASZAK, 1998). The plumbeous rail, Pardirallus sanguinolentus (SWAINSON, 1838), is one of three members of the genus Pardirallus Bonaparte, 1856, in South America. Six subspecies are recognized, three of which are partially distributed in Chile. This bird inhabits all types of wetlands, including brackish and 
freshwaters, which offer ideal conditions for the high presentation of parasitism (KAMIYA et al., 2014; LEUNG \& KOPRIVNIKAR, 2016). The previous records of parasites for plumbeous rail include both gastrointestinal and ectoparasites (see Table 1); however, these reports have been strongly biased toward taxonomic descriptions that either focus on specific parasite groups or species (e.g. CICCHINO, 2011; SKORACKI et al., 2014). The aim of this study was to identify the ecto and gastrointestinal parasites of plumbeous rail in Chile.

\section{Materials and Methods}

Between June 2001 and March 2015, the anatomic organs of 26 adult birds from the Nuble Province, Biobío Region (36³7’S; $\left.71^{\circ} 57^{\prime} \mathrm{W}\right)$, were analyzed. The organs corresponded to museum skins of three birds (which were part of the Ornithological Collection of Avian Carcasses of the Zoology Laboratory of the Faculty of Veterinary Sciences, University of Concepción), ten carcasses whose deaths were attributed to road kills and poaching (retrieved by the Wildlife Rehabilitation Center, University of Concepción), and 13 gastrointestinal tracts. Ectoparasites were collected through plumage inspection (15 minutes per bird), followed by immediate preservation in $70 \%$ ethanol. Feather lice were mounted using Canada balsam following the techniques described by Palma (1978) and Price et al. (2003). Feather mites were cleared in Nesbitt solution ( $40 \mathrm{~g}$ of chloral hydrate, $25 \mathrm{~mL}$ of distilled water, and $2.5 \mathrm{~mL}$ of hydrochloric acid) for 72 hours and were later mounted in Berlese solution (KRANTZ \& WALTER, 2009). For the endoparasites, the dissection of birds and the collection and preservation of helminths followed the methods of Kinsella \& Forrester (1972). The keys used for taxonomic identification

Table 1. Checklist of parasites found in plumbeous rail, Pardirallus sanguinolentus, to date.

\begin{tabular}{|c|c|c|}
\hline Parasite & Location & Reference \\
\hline \multicolumn{3}{|l|}{ Acari: Syringophilidae } \\
\hline Rafapicobia melzeri & Santiago Province, Chile & Skoracki et al. (2014) \\
\hline \multicolumn{3}{|l|}{ Acari: Pterolichidae } \\
\hline Grallobia sp. & Biobío Region, Chile & This study \\
\hline Grallolichus sp. & Biobío Region, Chile & This study \\
\hline \multicolumn{3}{|l|}{ Acari: Xolalgidae } \\
\hline Analloptes megnini & Biobío Region, Chile & This study \\
\hline \multicolumn{3}{|l|}{ Acari: Analgidae } \\
\hline Megniniella sp. & Biobío Region, Chile & This study \\
\hline Metanalges sp. & Biobío Region, Chile & This study \\
\hline \multicolumn{3}{|l|}{ Phthiraptera: Amblycera } \\
\hline Pseudomenopon meinertzhageni & $\begin{array}{c}\text { Brazil and Chile (location not specified); Buenos } \\
\text { Aires and Neuquén Provinces, Argentina; Biobío } \\
\text { Region, Chile }\end{array}$ & Price (1974); Cicchino (2011); this study \\
\hline \multicolumn{3}{|l|}{ Phthiraptera: Ischnocera } \\
\hline Rallicola andinus & $\begin{array}{c}\text { Lake Junín, Perú; Brazil (location not specified), } \\
\text { Buenos Aires and Tierra del Fuego Provinces, } \\
\text { Argentina; Biobío Region, Chile }\end{array}$ & $\begin{array}{c}\text { Carriker (1949); Emerson (1955); Cicchino } \\
\text { (2011); this study }\end{array}$ \\
\hline Rallicola pratti & Buenos Aires Province, Argentina & Cicchino (2011) \\
\hline Fulicoffula sp. & $\begin{array}{c}\text { Buenos Aires Province, Argentina; Biobío Region, } \\
\text { Chile }\end{array}$ & Cicchino (2011); this study \\
\hline \multicolumn{3}{|l|}{ Nematoda: Heterakidae } \\
\hline Heterakis psophiae & Biobío Region, Chile & This study \\
\hline \multicolumn{3}{|l|}{ Nematoda: Ascarididae } \\
\hline Porrocaecum ardeae & Biobío Region, Chile & This study \\
\hline \multicolumn{3}{|l|}{ Nematoda: Tetrameridae } \\
\hline Tetrameres sp. & Biobío Region, Chile & This study \\
\hline \multicolumn{3}{|l|}{ Nematoda: Capillariidae } \\
\hline Capillaria sp. & Biobío Region, Chile & This study \\
\hline \multicolumn{3}{|l|}{ Platyhelminthes: Cestoda } \\
\hline Diorchis sp. & Biobío Region, Chile & This study \\
\hline \multicolumn{3}{|l|}{ Platyhelminthes: Trematoda } \\
\hline Microphallus szidati & Buenos Aires Province, Argentina & Martorelli (1986) \\
\hline Echinostoma parcespinosum & Buenos Aires Province, Argentina & Martorelli (1987) \\
\hline \multicolumn{3}{|l|}{ Acanthocephala: Plagiorhynchidae } \\
\hline Plagiorhynchus sp. & Biobío Region, Chile & This study \\
\hline
\end{tabular}


adopted the approach of Carriker (1949), Emerson (1955), Price (1974), and Cicchino (2011) for feather lice; Trouessart (1885), Gaud (1958), and Gaud \& Mouchet (1963) for feather mites; and Yamaguti (1961, 1963) and Khalil et al. (1994) for helminths.

To quantify the parasite community, we determined the inverse Simpson diversity index, as follows:

$$
\mathrm{D}=1 /\left(\sum \mathrm{p}_{\mathrm{i}}^{2}\right)
$$

where $\mathrm{p}$ is the proportional biomass of species $\mathrm{i}$, species richness $(S)$, and evenness (D/S) (WILSEY et al., 2005).

All parasite specimens were deposited in the Collection of Parasites of Chile, Zoology Laboratory, Faculty of Veterinary Science, University of Concepción, Chile, under the codes CDCA 132 to 136 for mites, UdeCPhsa 147 to 168 for lice and CDCA 180 to 182 for helminths.

\section{Results and Discussion}

\section{Ectoparasites}

Acari: All inspected birds were parasitized with at least one mite species (Table 2): Analloptes megnini Trouessart (1885), Grallobia sp., Grallolichus sp., Megniniella sp., or Metanalges sp.

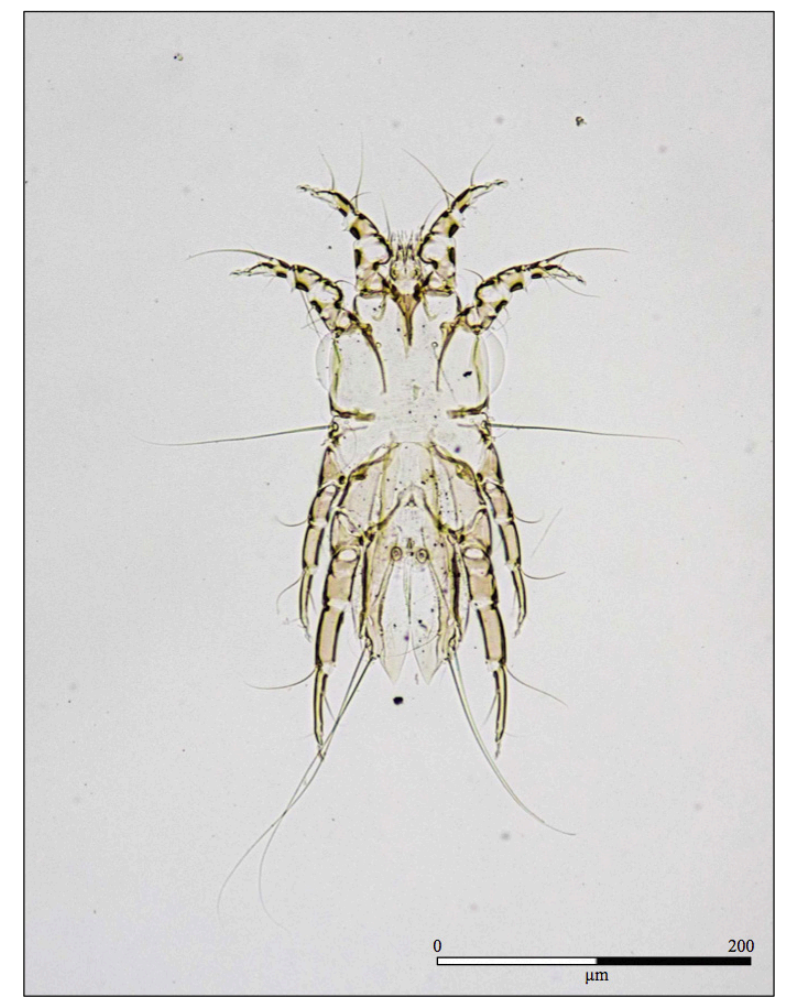

Figure 1. Light microscopy of ventral view of male Analloptes megnini.

Table 2. Ecto and gastrointestinal parasites found in 26 plumbeous rails, Pardirallus sanguinolentus, between 2001-2015 in Central Chile.

\begin{tabular}{|c|c|c|c|c|c|}
\hline Parasite & Prevalence (\%) & Range & Mean intensity & $\begin{array}{c}\text { Number of } \\
\text { parasitized birds }\end{array}$ & $\begin{array}{c}\text { Total of } \\
\text { parasites }\end{array}$ \\
\hline \multicolumn{6}{|l|}{ Acari: Pterolichidae } \\
\hline Grallobia sp.* & 80 & $0-22$ & 7 & 8 & 56 \\
\hline Grallolichus sp.* & 10 & $0-13$ & 13 & 1 & 13 \\
\hline \multicolumn{6}{|l|}{ Acari: Xolalgidae } \\
\hline Analloptes megnini* & 10 & $0-1$ & 1 & 1 & 1 \\
\hline \multicolumn{6}{|l|}{ Acari: Analgidae } \\
\hline Megniniella sp.* & 30 & $0-1$ & 1 & 3 & 3 \\
\hline Metanalges sp.* & 80 & $0-4$ & 2.1 & 8 & 17 \\
\hline \multicolumn{6}{|l|}{ Phthiraptera: Amblycera } \\
\hline Pseudomenopon meinertzhageni & 61.5 & $0-6$ & 3.1 & 8 & 25 \\
\hline \multicolumn{6}{|l|}{ Phthiraptera: Ischnocera } \\
\hline Rallicola andinus & 100 & $2-22$ & 10.9 & 13 & 142 \\
\hline Fulicoffula sp. & 15.4 & $0-7$ & 4 & 2 & 8 \\
\hline \multicolumn{6}{|l|}{ Nematoda: Heterakidae } \\
\hline Heterakis psophiae* & 52.2 & $0-6$ & 2.9 & 12 & 35 \\
\hline \multicolumn{6}{|l|}{ Nematoda: Ascarididae } \\
\hline Porrocaecum ardeae* & 13 & $0-6$ & 2.7 & 3 & 8 \\
\hline \multicolumn{6}{|l|}{ Nematoda: Tetrameridae } \\
\hline Tetrameres sp. $\$$ & 4.3 & $0-5$ & 5 & 1 & 5 \\
\hline \multicolumn{6}{|l|}{ Nematoda: Capillariidae } \\
\hline Capillaria sp. ${ }^{\S}$ & 4.3 & $0-7$ & 7 & 1 & 7 \\
\hline \multicolumn{6}{|l|}{ Platyhelminthes: Cestoda } \\
\hline Diorchis sp.* & 13 & $0-7$ & 3 & 3 & 9 \\
\hline \multicolumn{6}{|l|}{ Acanthocephala: Plagiorhynchidae } \\
\hline Plagiorhynchus sp.* & 4.3 & $0-1$ & 1 & 1 & 1 \\
\hline
\end{tabular}

${ }^{*}$ New record for plumbeous rail and Chile; $§ N e w$ record for plumbeous rail. 
A male individual of $A$. megnini (Astigmata: Xolalgidae) (Figure 1) was found on one bird. Despite the small number of individuals analyzed, low prevalence rates were frequently found among the Analloptes Trouessart, 1885 species. Miller et al. (1997) commented that this will likely underestimate the presence of this genus, as it generally occurs in small quantities. Furthermore, these mites inhabit downy and covert feathers, which may hinder the collection of this genus. The genus Analloptes includes 11 species that parasitize phylogenetically distant hosts, including Coraciiformes, Gruiformes, Pelecaniformes, Accipitriformes, and Passeriformes (GAUD, 1968; MIRONOV \& HERNANDES, 2014).

Grallobia sp. (Astigmata: Pterolichidae) (Figure 2) presented with the highest prevalence rates in this study $(80 \%)$. A similar result was found in american coot Fulica americana Gmelin, 1789, which was affected by G. fulicae Trouessart, 1885, with a prevalence of $82.4 \%$ (ROUAG-ZIANE et al., 2007). Conversely, Grallolichus sp. (Figure 3) had a prevalence of $10 \%$ and a mean intensity of 13.0. These mites were morphologically similar to the species G. minutus Gaud \& Mouchet, 1963. Both genera, as well as all mites from the family Pterolichidae, inhabit the surface of feathers with large vanes, such as flight and covert feathers of the wings and tail (MIRONOV \& DABERT, 2007). These mites affect a rather homogeneous group of birds; Grallobia Hull, 1932 is only associated with the avian family Rallidae, whereas Grallolichus Gaud, 1960 is associated with Rallidae, Jacanidae, and Heliornithidae (GAUD, 1968; GAUD \& MOUCHET, 1963).

Both Megniniella sp. and Metanalges sp. (Astigmata: Analgidae) (Figures 4 and 5) were found in three (30\%) and eight (80\%) birds, respectively. Unlike most other genera from the subfamily Megniniinae, Megniniella Gaud \& Mouchet, 1959 and Metanalges Truessart, 1919 occur almost exclusively on birds of the family Rallidae (GAUD, 1968; GAUD \& ATYEO, 1982), and they are often found in downy and covert feathers. The genus Megniniella has seven species, six of which are described from New and Old World rallids (MIRONOV \& GALLOWAY, 2002). Conversely, 11 species make up the genus Metanalges, which are allocated to the subgenera Metanalges and Agrialges Gaud \& Mouchet, 1959, both of which are exclusive to rallids (GAUD \& MOUCHET, 1959; MIRONOV \& GALLOWAY, 2002). The individuals collected here could not be taxonomically identified beyond genus; nevertheless, they shared several similarities with Megniniella gallinulae Buchholz (1869), Metanalges crexi Mironov, 1985, and M. rallorum Trouessart (1885), respectively.

Lice: All birds were parasitized with at least one species of the feather lice Pseudomenopon meinertzhageni Price, 1974, Rallicola andinus Carriker, 1949, and Fulicoffula sp. (Table 2).

Pseudomenopon meinertzhageni (Phthiraptera: Amblycera) (Figure 6) was found in eight birds (61.5\%). Lice from this genus can be found in the hosts Gruiformes, Podicipediformes, and Charadriiformes, and they essentially feed on contour feather barbs and are occasionally recorded with hematophagous behavior (CICCHINO, 2011). According to Lakshminarayana (1977), lice from this genus are widely distributed in birds from the family Rallidae. Pseudomenopon meinertzhageni was exclusively recorded in plumbeous rail in Brazil, Chile, and Argentina (PRICE, 1974; CICCHINO \& CASTRO, 1998a; CICCHINO, 2011).

Rallicola andinus (Phthiraptera: Ischnocera) (Figure 7) was found in all analyzed birds. Rallicola Johnston \& Harrison, 1911 is composed of 55 species, all of which are parasites of Guiformes and Chardriiformes birds (CICCHINO \& CASTRO, 1998b). Since the first description of Rallicola andinus in plumbeous rail in Peru (CARRIKER, 1949), this parasite has been recorded in Brazil, Argentina, and Chile (EMERSON, 1955; CICCHINO \& EMERSON, 1983; CICCHINO, 2011).

Two birds (15.4\%) presented with Fulicoffula sp. (Phthiraptera: Ischnocera) (Figure 8). This genus was originally erected to allocate all Ischnocera Kellogg, 1896 species with an elongated shape found on rallid birds (EMERSON \& PRICE, 1967). The specimens found shared similarities with $F$. americana Emerson, 1960, but with notable differences in size. Equally, Cicchino (2011) recently found a similar Fulicofulla Clay \& Meinertzhagen, 1938 species on plumbeous rail that likely corresponded to a new species.

\section{Gastrointestinal parasites}

In 23 birds, six helminth species were found (Table 2) to be distributed in the phylum Nematoda: Heterakis psophiae Travassos, 1913, Porrocaecum ardeae Frölich (1812), Tetrameres sp., and Capillaria sp.; Platyhelminthes: Diorchis sp.; and Acanthocephala: Plagiorhynchus sp.

Nematoda: Heterakis psophiae (Ascaridida) (Figure 9) was a helminth with a higher prevalence rate $(52.2 \%)$ and mean intensity (2.9). This parasite was found in the cecal lumen of 12 birds, as usually reported for members of this genus (ATKINSON et al., 2008). These parasites present a direct life cycle and worldwide distribution (ATKINSON et al., 2008), and they have been recorded on two previous occasions in Chile: H. gallinarum (Shrank, 1788) in eared dove Zenaida auriculata (Des Murs, 1847) in Nuble, as well as H. dispar (Shrank, 1790) in upland goose Chloephaga picta (Gmelin, 1789) in the Magallanes region (GONZÁLEZ et al., 2004; GONZÁLEZ et al., 2005). Heterakis psophiae was described by Travassos (1913) from green-winged trumpeter Psophia viridis Spix, 1825 in Brazil; thus far, this parasite corresponds to the only known Heterakis species from South American Gruiformes.

Porrocaecum ardeae (Ascaridida) (Figure 10) was found in three birds (13\%). One bird presented this parasite underneath the parietal peritoneum and mesentery of its body cavity (coelom), as well as in the lumen of the small intestine, which was perforated. This does not seem to be an isolated incident given that Fanke et al. (2011) reported the death of three common crane, Grus grus Linnaeus (1758), due to intestinal perforation caused by severe infestation with this parasite. Species of the genus Porrocaecum Railliet $\&$ Henry, 1912 are cosmopolitan and present indirect life cycles; invertebrates serve as an intermediate host (ATKINSON et al., 2008; DZIEKONSKA-RYNKO et al., 2015). There are several records of $P$. ardeae regularly affecting birds of the families Gruidae and Ardeidae in Europe and Central America (SCHMIDT \& NEILAND, 1973; HARTWICH, 1979; FANKE et al., 2011; 


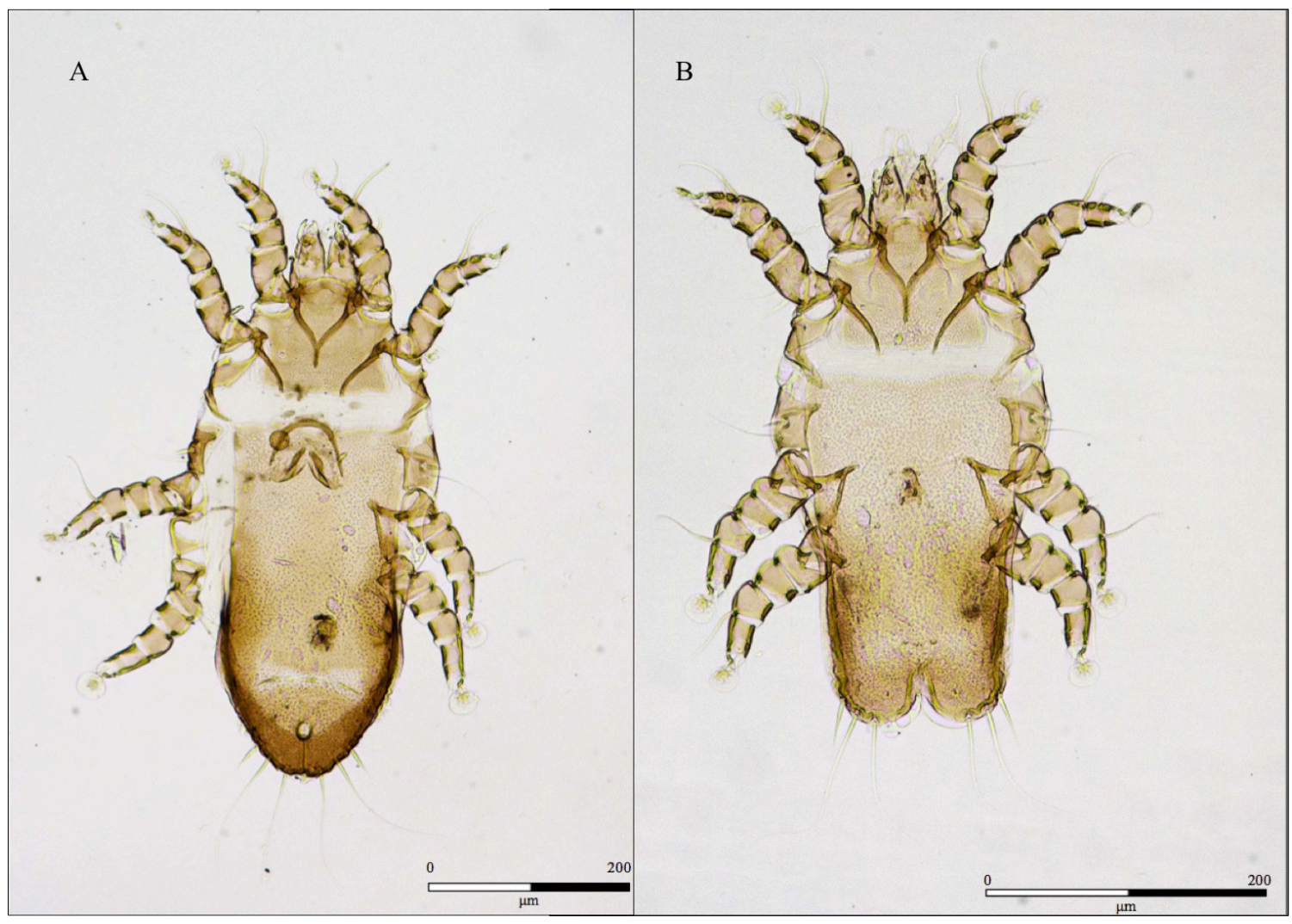

Figure 2. Light microscopy of ventral view of female (A) and male (B) Grallobia sp.

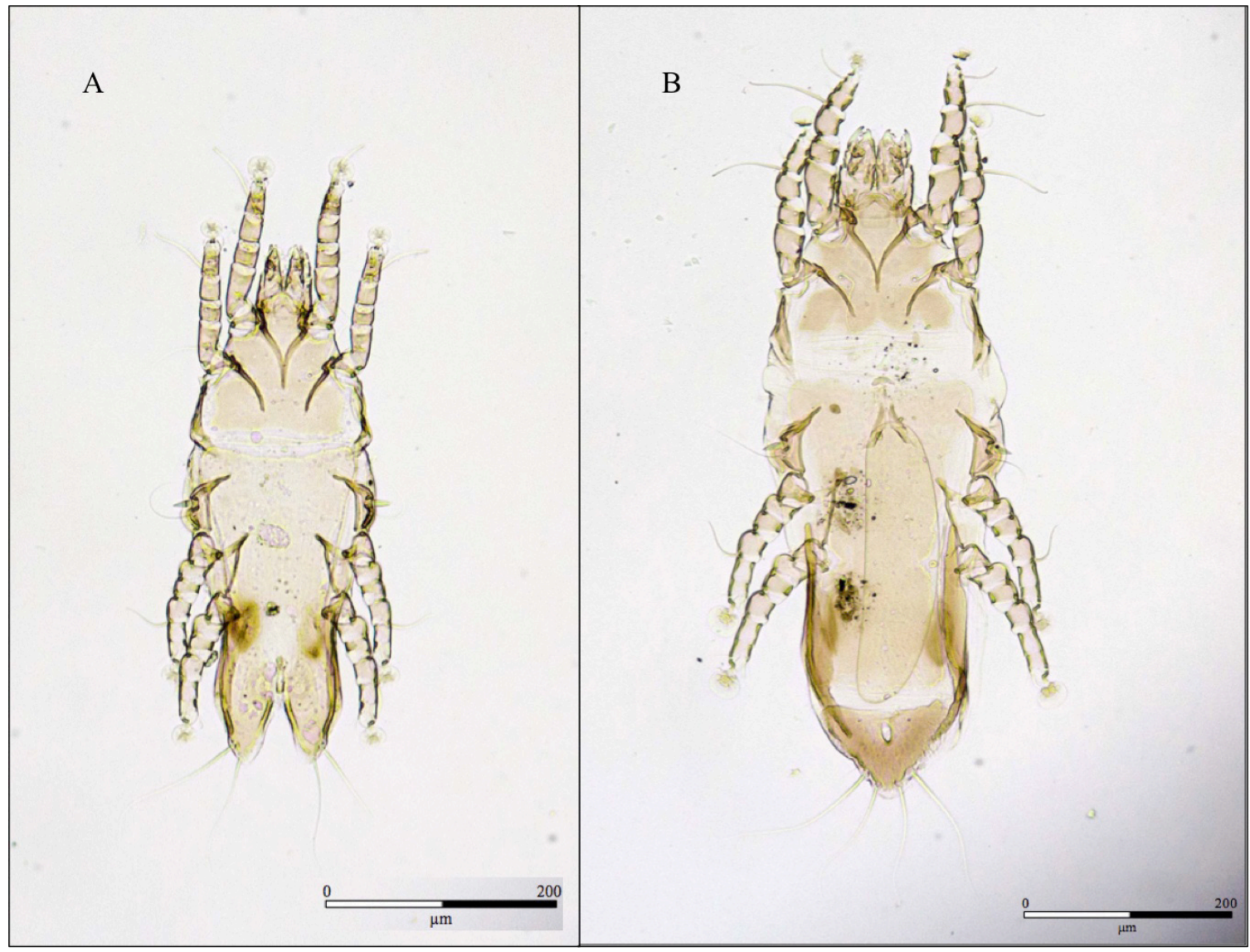

Figure 3. Light microscopy of ventral view of male (A) and female with egg (B) Grallolichus sp. 


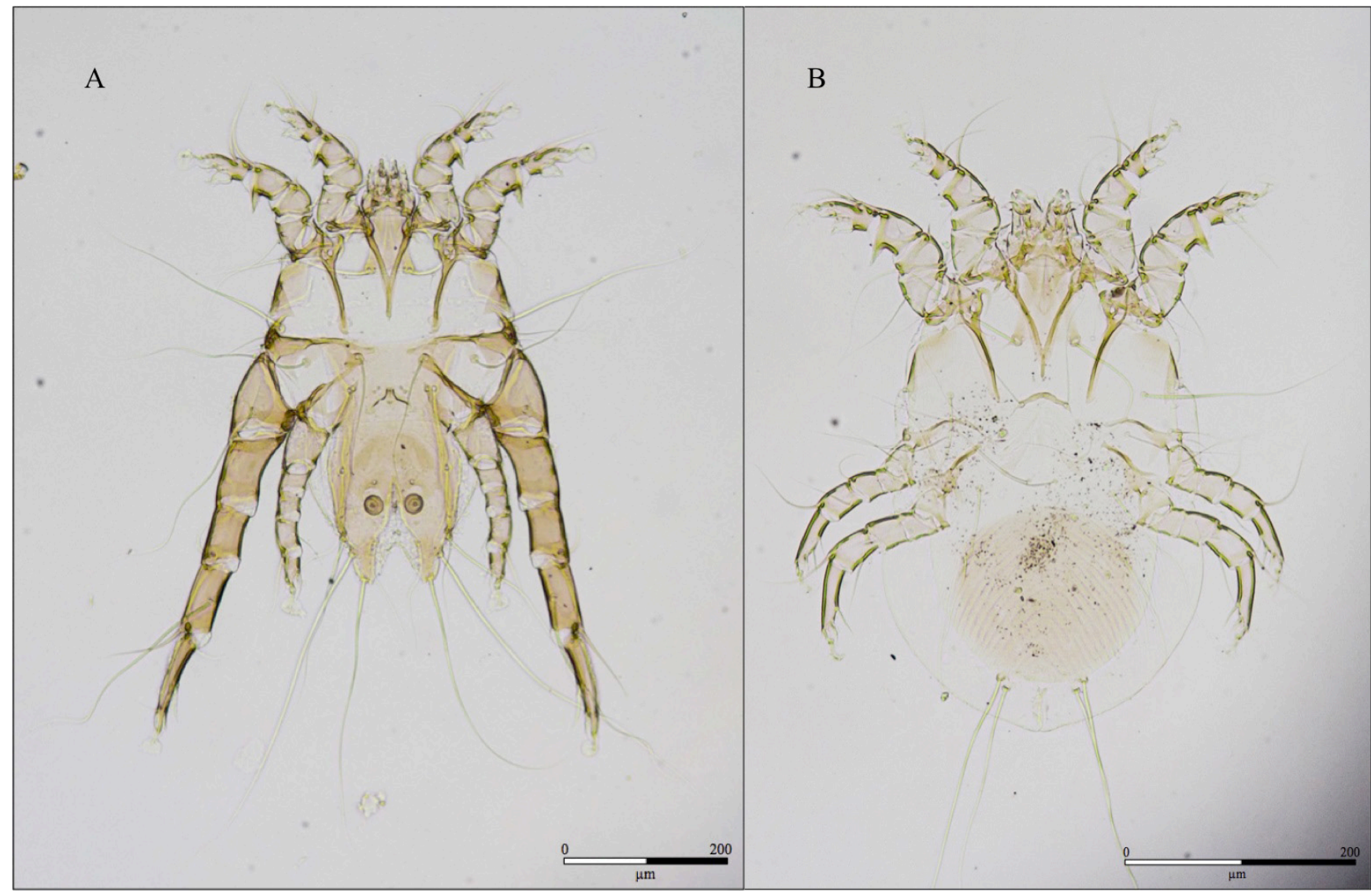

Figure 4. Light microscopy of ventral view of male (A) and female (B) Megniniella sp.

A

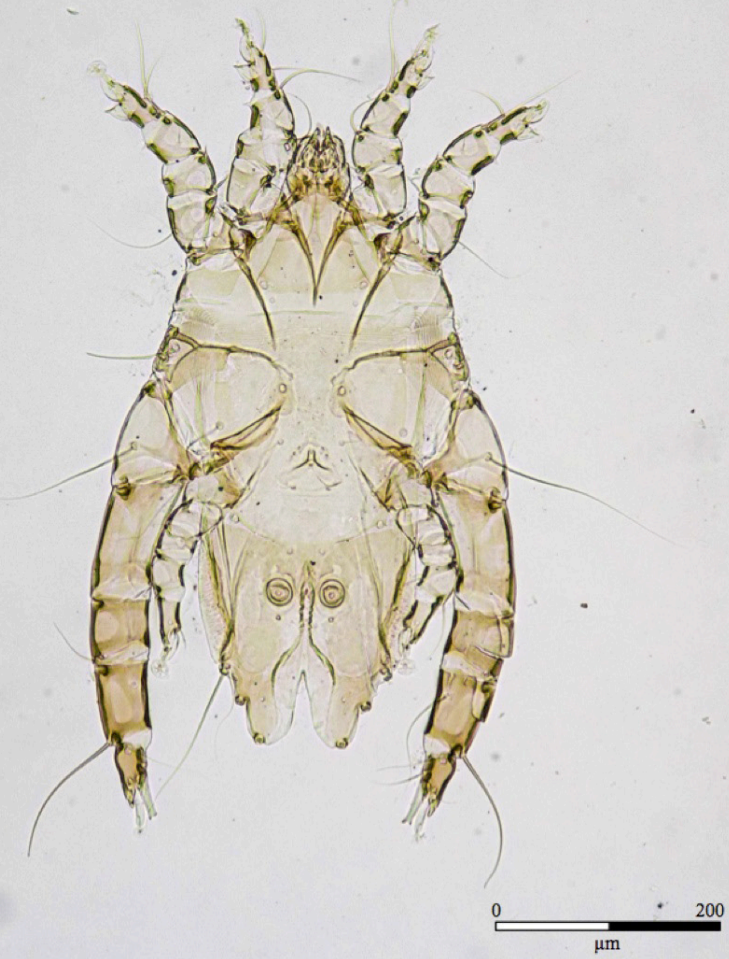

B

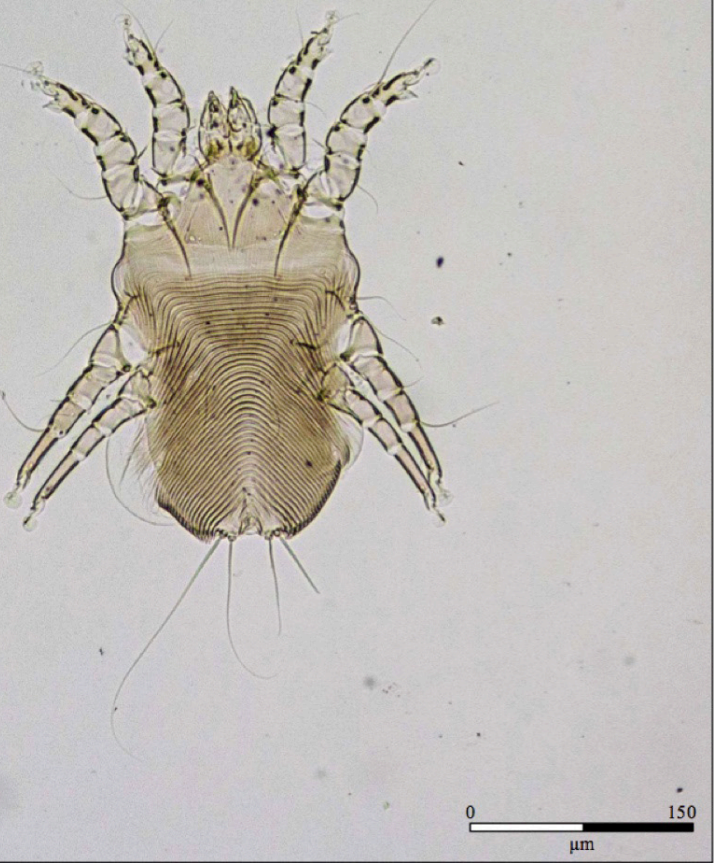

Figure 5. Light microscopy of Metanalges sp. showing ventral view of male (A) and female (B). 
DZIEKONSKA-RYNKO et al., 2015; SITKO \& HENEBERG, 2015).

In one bird (4.3\%), seven individuals from the genus Capillaria Zeder, 1800 (Capillariidae) were found (Figure 11). The parasites were in the final portion of the small intestine and a few were identified in the caecum. These parasites have a worldwide distribution and there are several records of its existence in Chile (e.g., HINOJOSA-SÁEZ \& GONZÁLEZ-ACUÑA, 2005; GONZÁLEZACUÑA et al., 2010; VALDEBENITO et al., 2015). Among all members of this genus, Capillaria fulicae Pavlov \& Borgarenko (1959) is often found in rallid birds from North America (KINSELLA, 1973; KINSELLA et al., 1973). In addition to its distinctive morphological features, there are no Capillaria species described for South American rallids; therefore, this parasite is a good fit as a possible new species. Further studies need to be conducted to verify whether this does, in fact, represent a new species.

Five females from the genus Tetrameres Creplin, 1846 (Tetrameridae) were found in one bird (4.3\%). These nematodes

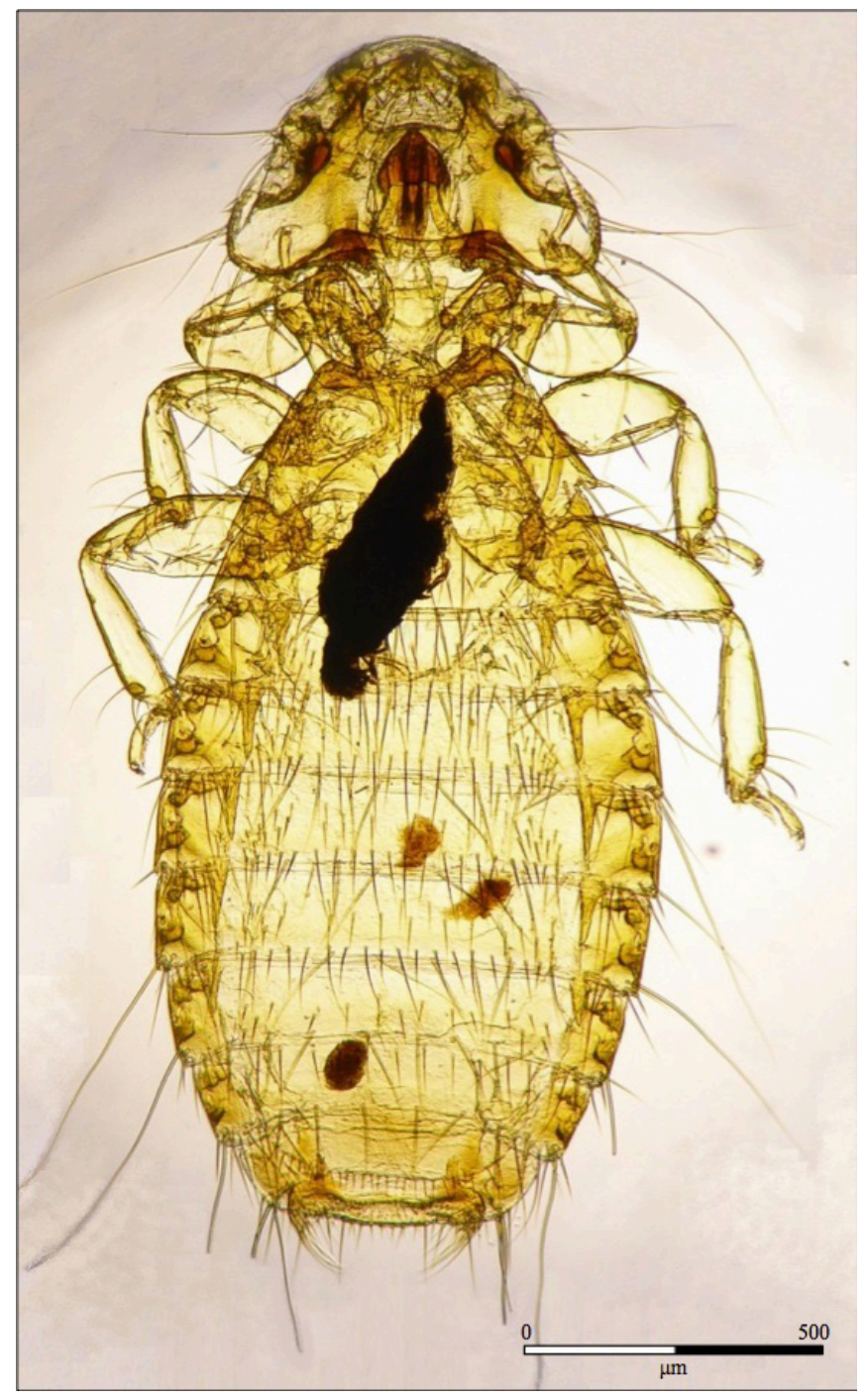

Figure 6. Light microscopy of Pseudomenopon meinertzhageni showing ventral view of female. are widely distributed and can affect captive and wild birds. Female Tetrameres are typically attached to the proventriculus of the definitive host, while males tend to move more freely and are more likely to be found on the mucosa or lumen (ANDERSON, 2000). On certain occasions, Tetrameres species were recorded to affect terrestrial birds (e.g., Passeriformes and Galliformes); however, their main hosts are aquatic birds like Anseriformes, Pelecaniformes, Charadriiformes, and Gruiformes (MOLLHAGEN, 1976; ATKINSON et al., 2008), where T. fissispina Diesing, 1861, T. globosa Linstow (1879), and Tetrameres sp. were found to affect several species around the world (KINSELLA et al., 1973; MOLLHAGEN, 1976; AL-AWADI et al., 2010; BIRMANI et al., 2011).

Platyhelminthes: In the lumen of the small intestine of three birds (13\%), nine parasites were found in poor condition;

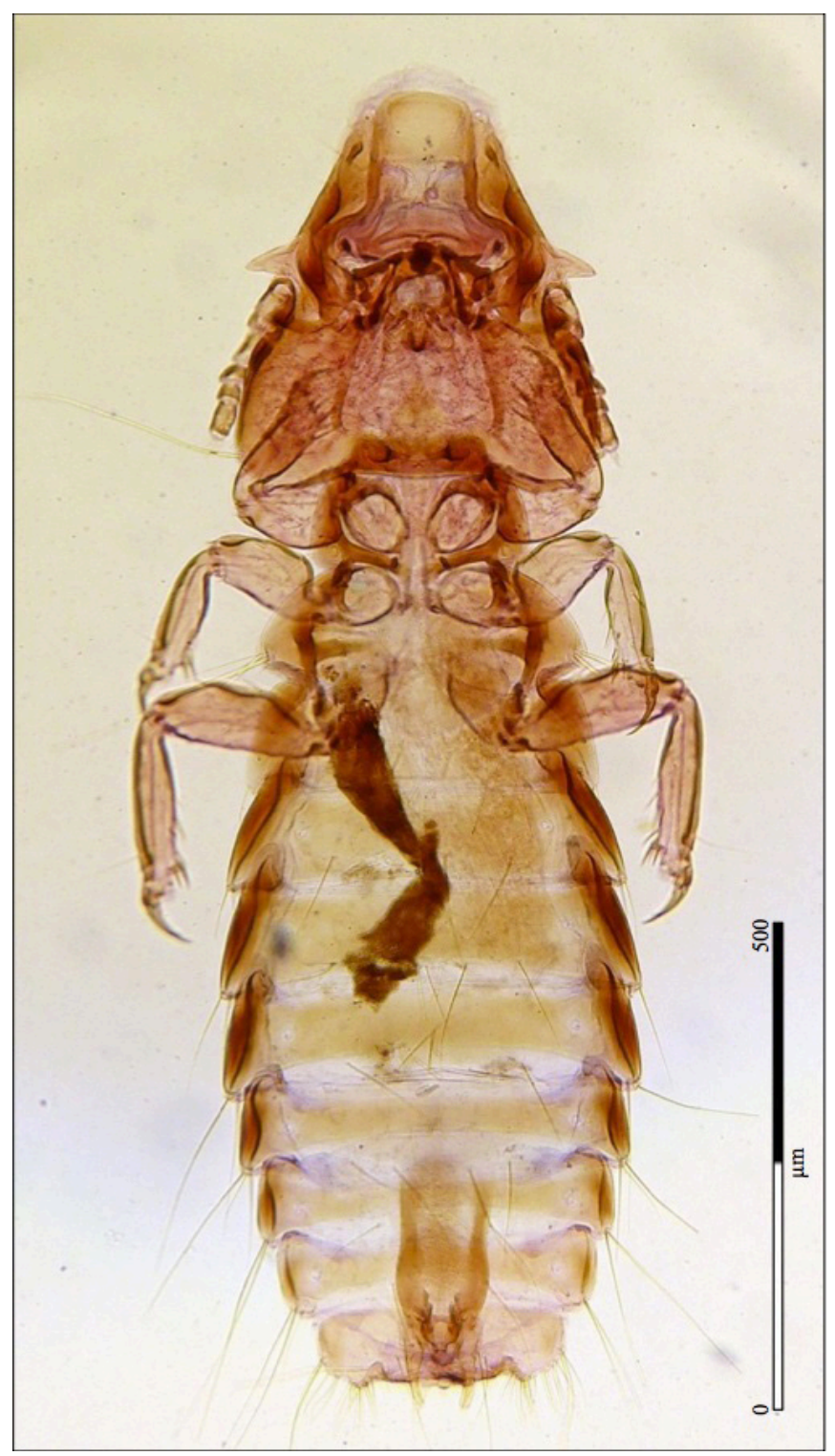

Figure 7. Light microscopy of Rallicola andinus showing ventral view of male. 


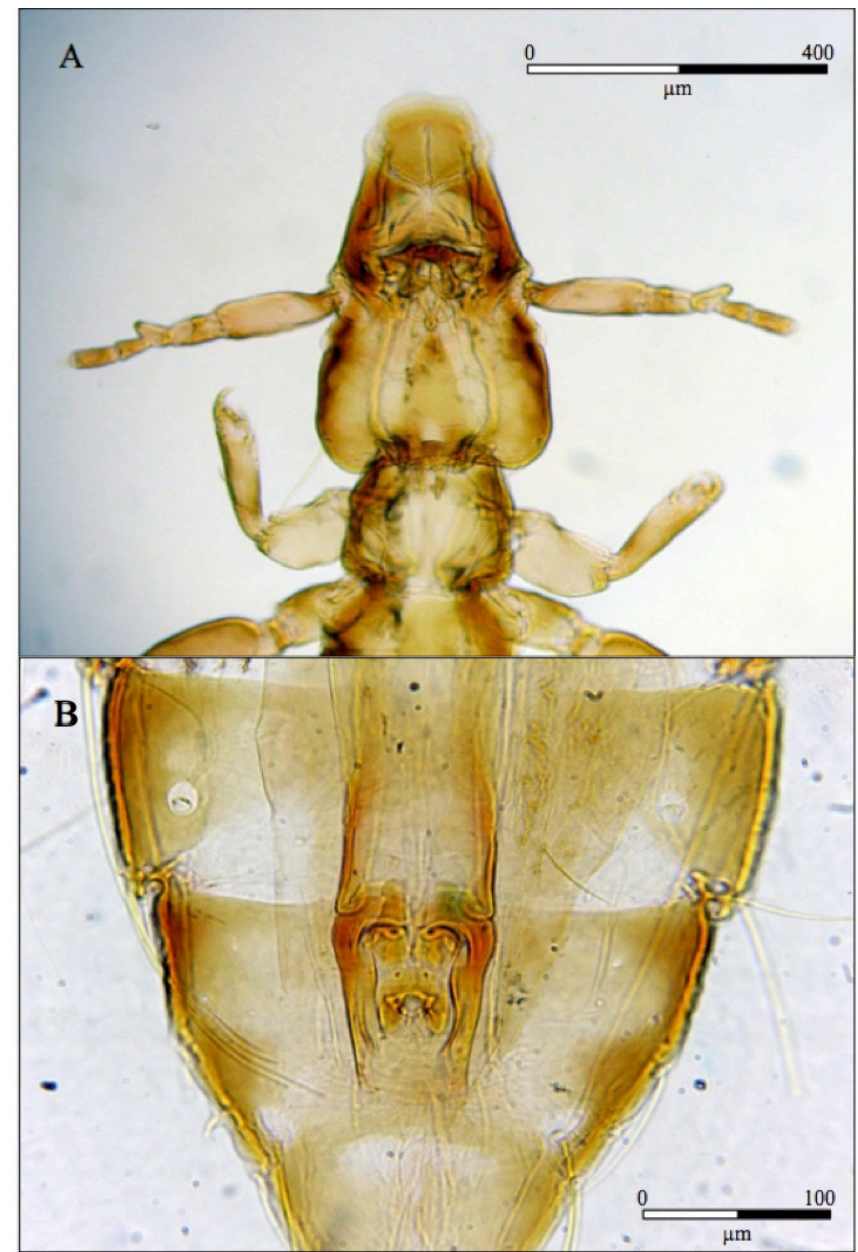

Figure 8. Light microscopy of Fulicoffula sp. showing head (A) and geniatalia (B) of male.

however, given their rostellum (Figure 12) with 8 hooks $80 \mu \mathrm{m}$ in length, they were placed in the genus Diorchis Clerc, 1903 (Cestoda: Hymenolepididae). This genus appears to commonly affect the avian families Anatidae, Rallidae and, occasionally, Charadriiformes (MARINOVA et al., 2015). While several Diorchis species have been collected from Fulica Linnaeus, 1758 birds (e.g., MCLAUGHLIN, 1986; GUILLÉN \& MORALES, 2003; LUNASCHI et al., 2012), only D. ralli Jones, 1944 was found in rallids, affecting king rail, Rallus elegans Audubon, 1834, in North America (JONES, 1944).

Acanthocephala: In one bird (4.3\%), one individual from the genus Plagiorhynchus Lühe (1911) (Plagiorhynchidae) was found. These parasites have a global distribution and were recorded in several bird orders (YAMAGUTI, 1963), including rallids (YOSHINO et al., 2009; ONUMA et al., 2011). All members of this phylum present an indirect life cycle, and invertebrates serve as intermediate host and occur exclusively in the small intestine of the definitive host (ATKINSON et al., 2008).

The overall parasite diversity and evenness was 4.64 and 0.332 , respectively. Both ectoparasites and helminths had a similar species diversity index (inverse Simpson index: ectoparasites, 2.91;

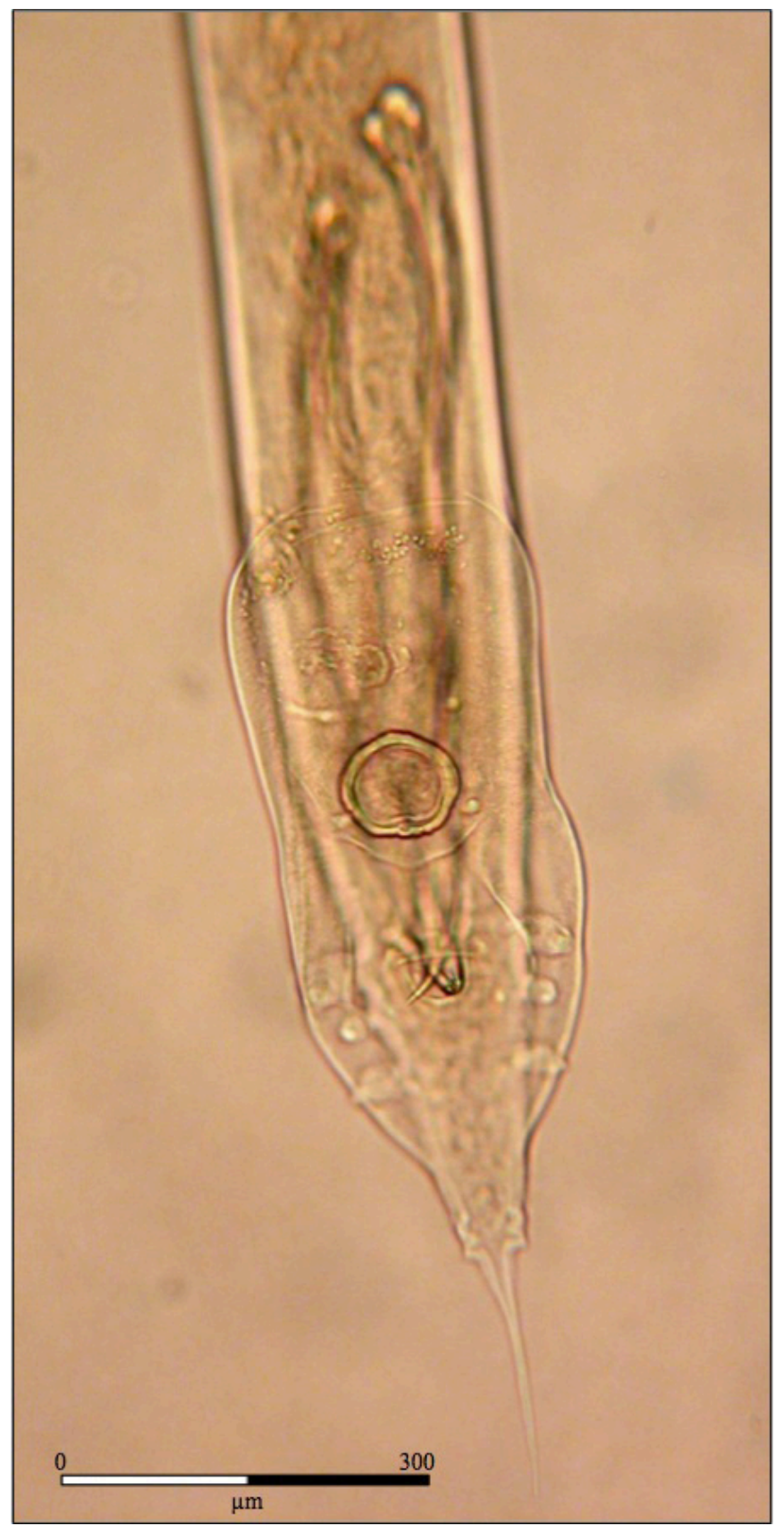

Figure 9. Light microscopy of Heterakis psophiae showing posterior end of male.

helminths, 2.92), whereas evenness was higher in helminths (0.487) when compared to ectoparasites (0.364). High parasite diversity is generally attributed to numerous factors including, for example, high latitude, large body size, and various habitat characteristics (KAMIYA et al., 2014). For plumbeous rail, habitat seems to be the primary contributing factor for the relatively high degree of diversity found. Wetlands have been shown to be advantageous for parasite communities, as there is a greater opportunity for contact with the various stages of parasite infection and/or the consumption of infected hosts (LEUNG \& KOPRIVNIKAR, 2016). These ecosystems also serve as stopover point for many 


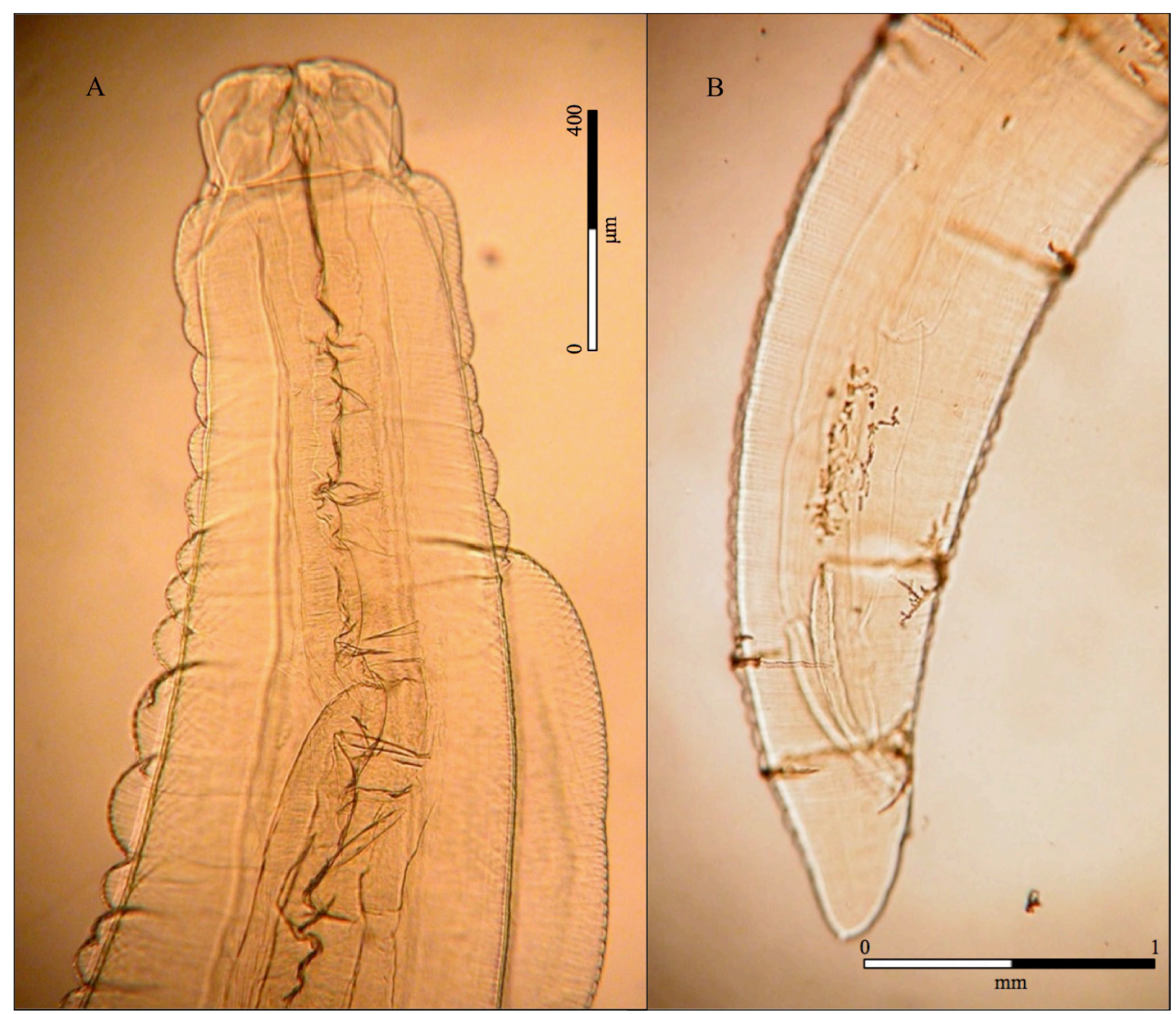

Figure 10. Light microscopy of Porrocaecum ardeae showing anterior end of female (A) and posterior end of male (B).

migrant bird species usually presenting elevated parasite diversity (LEUNG \& KOPRIVNIKAR, 2016). Additionally, studies on sympatric species, including various birds from the family Ardeidae (NAVARRO et al., 2005) and F. americana (CANARIS \& WALDMANN, 2017), have shown similar species richness and diversity.

Although Skoracki et al. (2014) did not report information on the prevalence of Rafapicobia melzeri (Table 1), we speculate that this absence was due to the relatively small numbers of birds examined. Cicchino (2011) found the louse Rallicola pratti on birds from Buenos Aires Province, Argentina (Table 1), which were located close to the area where the hosts blackish rail $P$. nigricans Vieillot, 1819 and plumbeous rail overlap in terms of their distribution. Therefore, this louse could likely only occur on plumbeous rail in areas where there is a close relationship between these two rallids. On the other hand, the absence of the trematodes Microphallus szidati and Echinostoma parcespinosum (Table 1) recorded in Argentina (MARTORELLI, 1986; MARTORELLI, 1987) were likely due to the absence of their intermediate hosts, which are needed to complete their life cycle. However, must be noted that the snail Pomacea canaliculata Lamarck (1828), an intermediate host of E. parcespinosum, was recently introduced to Chile and first reported by Jackson \& Jackson (2009) in the Coquimbo Region. Additionally, E. parcespinosum can abbreviate its life cycle in this snail by using it as a primary and secondary intermediate host (MARTORELLI, 1987), enabling the possibility of future presentation of this parasite in Chile.

The present study contributes to the understanding of parasite communities by supporting the current findings on the associations between habitat type and parasite richness and diversity (LEUNG 


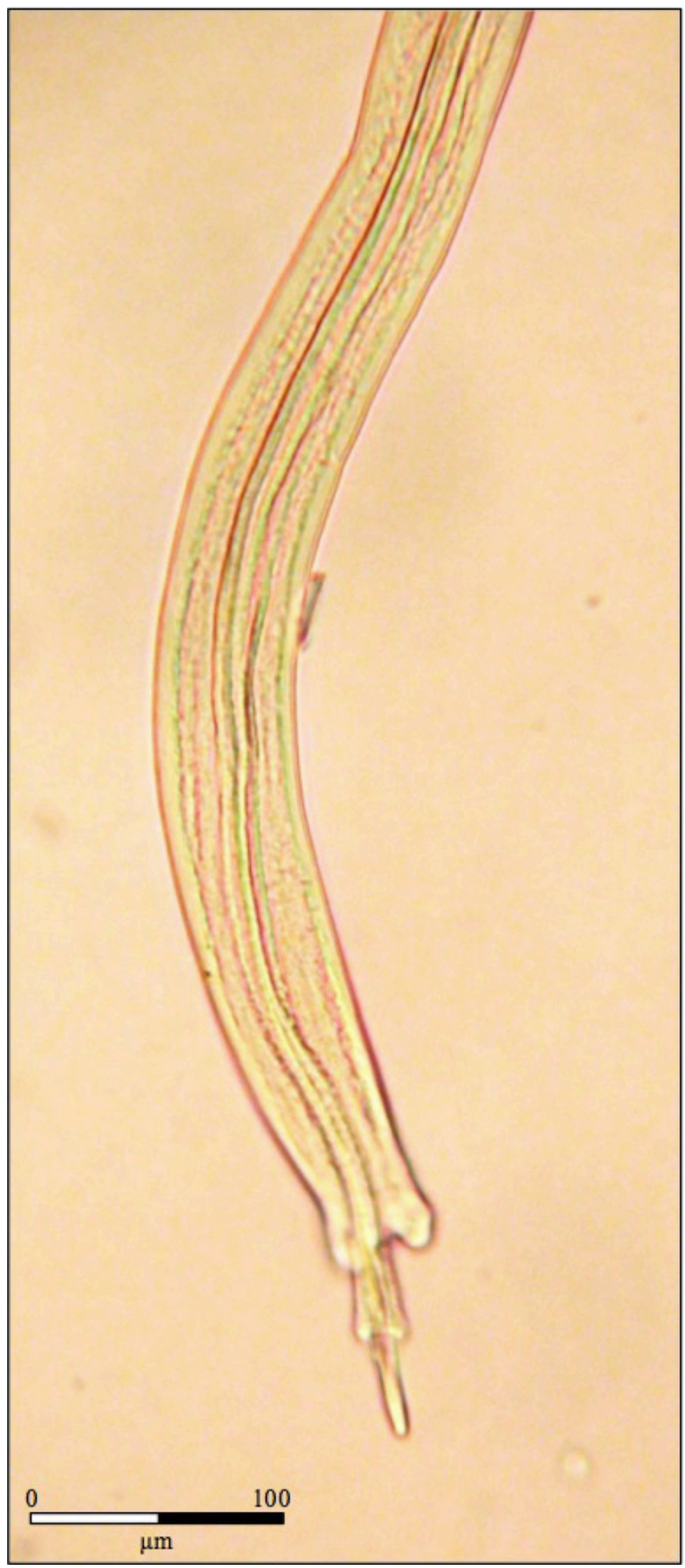

Figure 11. Light microscopy of Capillaria sp. showing posterior end of male.

\& KOPRIVNIKAR, 2016; GUTIÉRREZ et al., 2017). Plumbeous rail presented a high degree of parasite diversity, 14 species, including ecto and gastrointestinal parasites; these species featured 11 species that were not previously recorded in this host and nine not previously reported in Chile.

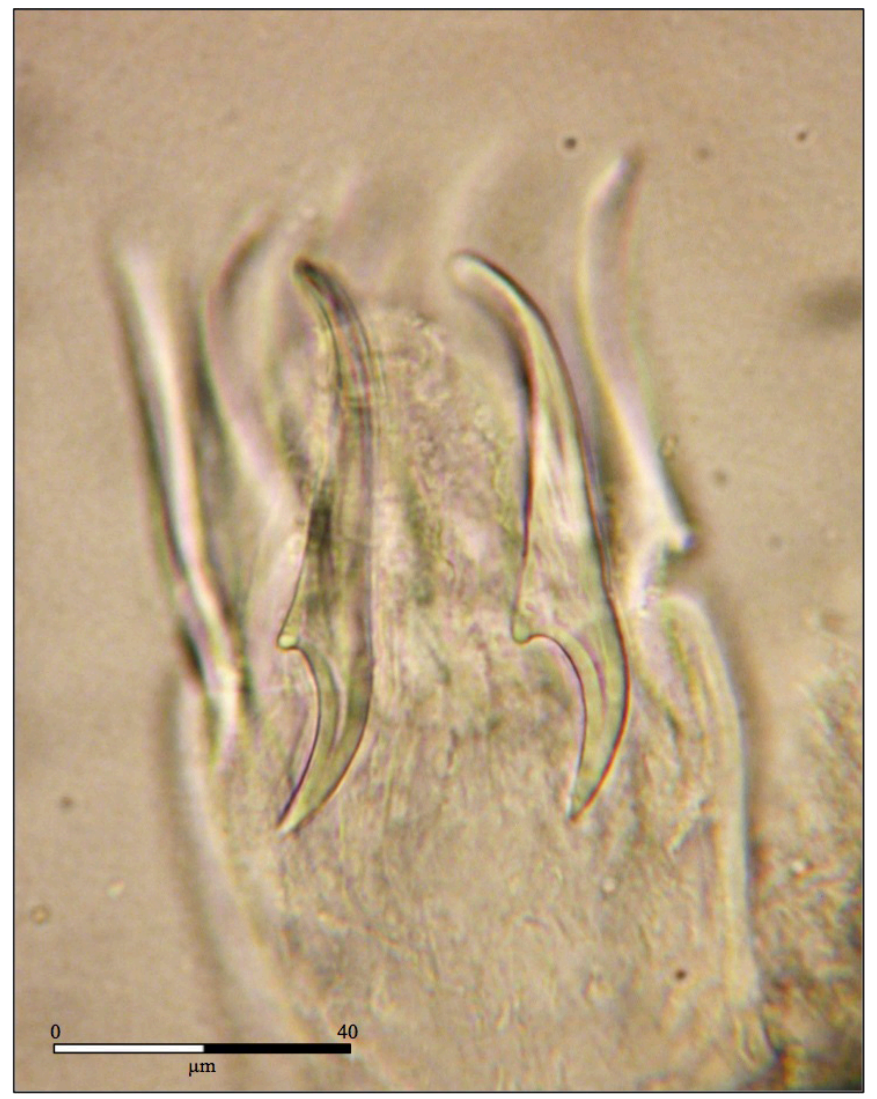

Figure 12. Light microscopy of Diorchis sp. showing hooks of rostellum.

\section{Acknowledgements}

The authors thank Carolina Silva de la Fuente, Gonzalo Torres, Pedro Pablo Álvarez, Karen Ardiles and Sofia González Ardiles for their support and help processing the samples, and Sebastián Muñoz-Leal for providing the abstract in Portuguese. This research work was founded by the Fondo Nacional de Desarrollo Científico y Tecnológico (FONDECYT) 1130948, 1170972. JOV was funded by the Comisión Nacional de Investigación Científica y Tecnológica (CONICYT), Becas Chile 72170569.

\section{References}

Al-Awadi H, Mhaisen F, Al-Joborae F. Helminth parasitic fauna of aquatic birds in Bahr Al-Najaf Depression, Mid Iraq. Bull Iraq Nat Hist Mus 2010; 11(2): 7-15.

Anderson RC. Nematode parasites of vertebrates: their development and transmission. 2nd ed. Wallingford: CABI Publishing; 2000. http://dx.doi. org/10.1079/9780851994215.0000.

Atkinson CT, Thomas NJ, Hunter DB. Parasitic diseases of wild birds. Ames: Wiley-Blackwell; 2008. http://dx.doi.org/10.1002/9780813804620.

Birmani NA, Dharejo AM, Khan MM. First record of the genus Tetrameres Creplin, 1846 (Nematoda: Tetrameridae) in Pakistan. Pak J Nematol 2011; 29(2): 213-218. 
Canaris AG, Waldmann ME. Metazoan parasites of the American Coot, Fulica americana, from the Rio Grande Valley in Colorado and Southwest, Texas, U.S.A., with a checklist of parasites for North America and West Indies. Comp Parasitol 2017; 84(2): 102-110. http://dx.doi. org/10.1654/1525-2647-84.2.102.

Carriker MA. Neotropical Mallophaga miscellany. V. New genera and species. Rev Bras Biol 1949; 9(3): 297-313.

Cicchino A, Castro DC. Amblycera. In: Morrone JJ, Coscarón S, editors. Biodiversidad de artrópodos Argentinos: una perspectiva biotaxonómica. Buenos Aires: Ediciones Sur; 1998a. p. 84-103.

Cicchino A, Castro DC. Ischnocera. In: Morrone JJ, Coscarón S, editors. Biodiversidad de artrópodos Argentinos: una perspectiva biotaxonómica. Buenos Aires: Ediciones Sur; 1998b. p. 104-124.

Cicchino AC, Emerson CK. Contribución al conocimiento de los malófagos Argentinos. XIV. Algunos Philopteridae (Mallophaga, Ischnocera) nuevos o poco conocidos parásitos de Rallidae (Aves, Gruiformes). Neotropica 1983; 29(82): 151-172.

Cicchino AC. Piojos (Insecta: Psocodea: Phthiraptera) parásitos de Gruiformes y Podicipediformes (Aves) en la Argentina: una aproximación sistemática, bioecológica y evolutiva [thesis]. Mar del Plata: Universidad Nacional de Mar del Plata; 2011.

Cunningham AA, Daszak P. Extinction of a species of land snail due to infection with a Microsporidian parasite. Conserv Biol 1998; 12(5): 1139-1141. http://dx.doi.org/10.1046/j.1523-1739.1998.97485.x.

Dziekonska-Rynko J, Mierzejewska K, Hliwa P. Parasitic helminths in grey heron (Ardea cinerea) chicks. Biologia 2015; 70(2): 279-282. http:// dx.doi.org/10.1515/biolog-2015-0022.

Emerson KC, Price RD. A new species of Fulicoffula (Mallophaga: Philopteridae) from Thailand. Entomol News 1967; 78(6): 163-166.

Emerson KC. A review of the genus Rallicola (Philopteridae, Mallophaga) found on Aramidae, Psophiidae and Rallidae. Ann Entomol Soc Am 1955; 48(4): 284-299. http://dx.doi.org/10.1093/aesa/48.4.284.

Fanke J, Wibbelt G, Krone O. Mortality factors and diseases in free-ranging Eurasian Cranes (Grus grus) in Germany. J Wildl Dis 2011; 47(3): 627637. http://dx.doi.org/10.7589/0090-3558-47.3.627. PMid:21719827.

Gaud J. Acariens plumicoles (Analgesoidea) parasites des oiseaux du Maroc. Bull Soc Sci Nat Phys Maroc 1958; 38: 27-49.

Gaud J. Acariens sarcoptiformes plumicoles (Analgoidea) parasites sur les oiseaux Ralliformes et Gruiformes d'Afrique. Belgique: Musée Royal de l'Afrique Centrale; 1968. 101 p. (Sciences Zoologiques; vol. 164).

Gaud J, Atyeo WT. The subfamilies of the Analgidae and Psoroptoididae (Acari: Analgoidea). J Med Entomol 1982; 19(3): 299-305. http://dx.doi. org/10.1093/jmedent/19.3.299.

Gaud J, Mouchet J. Acariens plumicoles (Analgesoidea) parasites des oiseaux du Cameroun 11. Analgesidae. Ann Parasitol Hum Comp 1959; 34(1-2): 149-208. http://dx.doi.org/10.1051/parasite/1959341149.

Gaud J, Mouchet J. Révision des genres Grallobia Hull et Grallolichus Gaud (Pterolichidae, Sarcoptiformes). Acarologia 1963; 5(4): 628-643.

González D, Daugschies A, Rubilar L, Pohlmeyer K, Skewes O, Mey E. Fauna parasitaria de la tórtola común (Zenaida auriculata, de Murs 1847) (Columbiformes: Columbidae) en Nuble, Chile. Parasitol Latinoam 2004; 59(1-2): 37-41. http://dx.doi.org/10.4067/S0717-77122004000100007.

González D, Skewes O, Candia C, Palma R, Moreno L. Estudio del parasitismo gastrointestinal y externo en caiquén Chloephaga picta
Gmelin, 1789 (Aves, Anatidae) en la Región de Magallanes, Chile. Parasitol Latinoam 2005; 60(1-2): 86-89. http://dx.doi.org/10.4067/ S0717-77122005000100016.

González-Acuña D, Moreno L, Cicchino A, Mironov S, Kinsella JM. Checklist of the parasites of the black-necked swan, Cygnus melanocoryphus (Aves: Anatidae), with new records from Chile. Zootaxa 2010; 2637(1): 55-68. http://dx.doi.org/10.11646/zootaxa.2637.1.3.

Guillén G, Morales E. First record of helminth parasites in Fulica ardesiaca (Aves: Rallidae) from Peru: Pantanos de Villa - Lima. Rev Peru Biol 2003; 10(2): 203-208.

Gutiérrez JS, Rakhimberdiev E, Piersma T, Thieltges DW. Migration and parasitism: habitat use, not migration distance, influences helminth species richness in Charadriiform birds. J Biogeogr 2017; 44(5): $1137-$ 1147. http://dx.doi.org/10.1111/jbi.12956.

Hartwich G. Ascariden (Nematoda, Ascaridoidea) aus Vögeln von Ungarn. Parasit Hung 1979; 12: 79-85.

Hinojosa-Sáez A, González-Acuña D. Estado actual del conocimiento de helmintos en aves silvestres de Chile. Gayana 2005; 69(2): 241-253.

Jackson D, Jackson D. Record of Pomacea canaliculata (Lamarck, 1822) (Ampullariidae), exotic mollusk for to North Chile. Gayana 2009; 73(1): 40-44.

Johnson PTJ, Lunde KB, Ritchie EG, Launer AE. The effect of trematode infection on amphibian limb development and survivorship. Science 1999; 284(5415): 802-804. http://dx.doi.org/10.1126/science.284.5415.802. PMid:10221912.

Jones AW. Diorchis ralli n. sp., a Hymenolepidid Cestode from the King Rail. Trans Am Microsc Soc 1944; 63(1): 50-53. http://dx.doi. org/10.2307/3223337.

Kamiya T, O’Dwyer K, Nakagawa S, Poulin R. What determines species richness of parasitic organisms? A meta-analysis across animal, plant and fungal hosts. Biol Rev Camb Philos Soc 2014; 89(1): 123-134. http:// dx.doi.org/10.1111/brv.12046. PMid:23782597.

Khalil LF, Jones A, Bray RA. Keys to the cestode parasites of vertebrates. Wallingfrord: CAB International; 1994.

Kinsella JM, Forrester DJ. Helminths of the Florida duck, Anas platyrhynchos fulvigula. Proc Helminthol Soc Wash 1972; 39(2): 173-176.

Kinsella JM, Hon LT, Reed PB. A comparison of the helminth parasites of the Common Gallinule (Gallinula chloropus cachinnans) and the Purple Gallinule (Porphyrula martinica) in Florida. Am Midl Nat 1973; 89(2): 467-473. http://dx.doi.org/10.2307/2424053.

Kinsella JM. Helminth parasites of the American Coot, Fulica americana americana, on its winter range in Florida. Proc Helminthol Soc Wash 1973; 40(2): 240-242.

Krantz GW, Walter DE. A manual of acarology. 3rd ed. Lubbock: Texas Tech; 2009.

Lakshminarayana KV. Notes on the genus Pseudomenopon with remarks on host relationships. Angew Parasitol 1977; 18(3): 152-162. PMid:920994.

Leung TL, Koprivnikar J. Nematode parasite diversity in birds: the role of host ecology, life history and migration. J Anim Ecol 2016; 85(6): 1471 1480. http://dx.doi.org/10.1111/1365-2656.12581. PMid:27496635.

Lunaschi L, Merlo H, Damborenea C. Type material housed in the Helminthological Collection of the Museo de La Plata, Buenos Aires, Argentina. Zootaxa 2012; 3199: 1-59. 
Marinova MH, Georgiev BB, Vasileva GP. Description of Diorchis thracica n. sp. (Cestoda, Hymenolepididae) from the Ruddy shelduck Tadorna ferruginea (Pallas) (Anseriformes, Anatidae) in Bulgaria. Syst Parasitol 2015; 91(3): 261-271. http://dx.doi.org/10.1007/s11230-015-9569-9. PMid:26063303.

Martorelli SR. Estudio sistemático y biológico de un digeneo perteneciente a la familia Microphallidae Travassos, 1920. I: Microphallus szidati sp. nov. parásito intestinal de Rallus sanguinolentus sanguinolentus (Aves, Rallidae) e Himantopus melanurus (Aves, Recurvirrostridae). Rev Iber Parasitol 1986; 46(4): 373-378.

Martorelli SR. Estudios parasitológicos en biotopos lenticos de la republica argentina. IV. El ciclo biológico de Echinostoma parcespinosum Lutz, 1924 (Digenea) parásito de Rallus maculatus maculatus y Rallus sanguinolentus sanguinolentus (Aves: Rallidae). Rev Mus La Plata 1987; 14(153): 47-62.

McLaughlin JD. Helminths of the Red-knobbed Coot (Fulica cristata) from Barberspan, Republic of South Africa. JWildl Dis 1986; 22(4): $577-$ 579. http://dx.doi.org/10.7589/0090-3558-22.4.577. PMid:3503147.

Miller MJ, Ewins PJ, Galloway TD. Records of ectoparasites collected on ospreys from Ontario. J Wildl Dis 1997; 33(2): 373-376. http://dx.doi. org/10.7589/0090-3558-33.2.373. PMid:9131582.

Mironov S, Hernandes FA. Two new species of the feather mite genus Analloptes (Trouessart, 1885) (Acariformes: Astigmata: Xolalgidae) from passerines (Aves: Passeriformes) in Brazil. Zootaxa 2014; 3889(4): 589 600. http://dx.doi.org/10.11646/zootaxa.3889.4.6. PMid:25544285.

Mironov SV, Dabert J. Three new feather mite genera of the Protolichus generic group (Astigmata, Pterolichidae) from parrots (Aves, Psittaciformes) of the Old World. Acta Parasitol 2007; 52(4): 386-402. http://dx.doi. org/10.2478/s11686-007-0042-z.

Mironov SV, Galloway TD. Four new species of feather mites (Acari: Analgoidea). Can Entomol 2002; 134(5): 605-618. http://dx.doi. org/10.4039/Ent134605-5.

Mollhagen TR. A study of the systematics and hosts of the parasitic nematode genus Tetrameres (Habronematoidea: Tetrameridae) [dissertation]. Lubbock: Texas Tech University; 1976.

Navarro P, Lluch J, Font E. The component helminth community in six sympatric species of Ardeidae. J Parasitol 2005; 91(4): 775-779. http:// dx.doi.org/10.1645/GE-3342.1. PMid:17089743.

Onuma M, Yoshino T, Zhao C, Nagamine T, Asakawa M. Parasitic helminths obtained from Okinawa Rails Gallirallus okinawae. J Yamashina Inst Ornithol 2011; 43(1): 74-81. http://dx.doi.org/10.3312/jyio.43.74.

Palma RL. Slide-mounting of lice: a detailed description of the Canada balsam technique. NZ Entomol 1978; 6(4): 432-436. http://dx.doi.org /10.1080/00779962.1978.9722313.

Pérez-Ponce de León G, García-Prieto L. Los parásitos en el contexto de la biodiversidad y la conservación. Biodiversitas 2001; 34: 11-15.

Price RD, Hellenthal RA, Palma RL, Johnson KP, Clayton DH. The chewing lice: world checklist and biological overview. Champaign: Illinois Natural History Survey; 2003.
Price RD. A Review of the genus Pseudomenopon (Mallophaga: Menoponidae). Ann Entomol Soc Am 1974; 67(1): 73-84. http://dx.doi. org/10.1093/aesa/67.1.73.

Rouag-Ziane N, Boulahbal A, Gauthier-Clerc M, Thomas F, Chabi Y. Inventaire et quantification des ectoparasites de la Foulque macroule Fulica atra (Gruiformes: Rallidés) dans Le Nord-Est De L'Algérie. Parasite 2007; 14(3): 253-256. http://dx.doi.org/10.1051/parasite/2007143253. PMid:17933305.

Schmidt GD, Neiland KA. Helminth fauna of Nicaragua. V. Cardiofilaria stepheni sp. n. (Onchocercidae) and other nematodes of birds. Proc Helminthol Soc Wash 1973; 40(2): 285-288.

Sitko J, Heneberg P. Composition, structure and pattern of helminth assemblages associated with central European herons (Ardeidae). Parasitol Int 2015; 64(1): 100-112. http://dx.doi.org/10.1016/j.parint.2014.10.009. PMid:25449288.

Skoracki M, Unsoeld M, Skorupski M, Kavetska K. Syringophilid mites (Acari: Syringophilidae) associated with the rails (Aves: Rallidae) and a key to the species of the genus Rafapicobia Skoracki, 2011. Syst Parasitol 2014; 88(3): 227-232. http://dx.doi.org/10.1007/s11230-014-9502-7. PMid:24935125.

Travassos L. Sobre as especies brazileiras da subfamília Heterakinae Railliet \& Henry. Mem Inst Oswaldo Cruz 1913; 5(3): 271-318. http://dx.doi. org/10.1590/S0074-02761913000300005.

Trouessart EL. Note sur le classification des Analgésiens et diagnoses d'espèces et de genres nouveaux. Bulletin de la Société d'Études Scientifiques d'Angers 1885; 14: 46-89.

Valdebenito JO, Moreno L, Landaeta-Aqueveque C, Kinsella JM, Mironov S, Cicchino A, et al. Gastrointestinal and external parasites of Enicognathus ferrugineus and Enicognathus leptorhynchus (Aves, Psittacidae) in Chile. Rev Bras Parasitol Vet 2015; 24(4): 422-431. http://dx.doi.org/10.1590/ S1984-29612015074. PMid:26648008.

Wilsey BJ, Chalcraft DR, Bowles CM, Willig MR. Relationships among indices suggest that richness is an incomplete surrogate for grassland biodiversity. Ecology 2005; 86(5): 1178-1184. http://dx.doi. org/10.1890/04-0394.

Yamaguti S. Systema Helminthum: the nematodes of vertebrates. New York: Interscience Publisher; 1961. (vol. 3).

Yamaguti S. Systema Helminthum: Acanthocephala. New York: Interscience Publisher; 1963. (vol. 5).

Yoshino T, Nakamura S, Endoh D, Onuma M, Osa Y, Teraoka H, et al. A helminthological survey of four families of waterfowl (Ardeidae, Rallidae, Scolopacidae and Phalaropodidae) from Hokkaido, Japan. J Yamashina Inst Ornithol 2009; 41(1): 42-54. http://dx.doi.org/10.3312/jyio.41.42. 